\title{
ANALISIS KINERJA KEUANGAN, SENSITIVITAS TERHADAP INFLASI DAN NILAI TUKAR SEBAGAI PREDIKTOR FINANCIAL DISTRESS
}

\author{
Oktavia Kurniawati ${ }^{1}$, Rr. Iramani ${ }^{2 *}$ \\ ${ }^{1,2}$ Universitas Hayam Wuruk Perbanas, Wonorejo Utara 16 Surabaya \\ *Penulis Korespondensi; Email: iramani@ perbanas.ac.id
}

\begin{abstract}
Abstrak
Mengidentifikasi kondisi financial distress sangat perlu dilakukan karena kondisi tersebut adalah merupakan peringatan dini sebelum terjadinya kebangkrutan. Kondisi financial distress dapat diprediksi dengan menggunakan model yang telah dikembangkan. Tujuan dari penelitian ini adalah untuk menguji dan menganalisis kinerja likuiditas, leverage, aktivitas, profitabilitas serta sensitivitas perusahaan terhadap inflasi dan nikai tukar sebagai prediktor financial distress pada perusahaan manufaktur yang terdaftar di Bursa Efek Indonesia pada tahun 2015 sampai dengan 2019. Teknik sampling yang digunakan dalam penelitian ini adalah purposive sampling. Sampel dalam penelitian ini meliputi 53 perusahaan yang mengalami financial distress dan yang tidak mengalami financial distress. Analisis data yang digunakan adalah Logistic Regression. Hasil penelitian ini menunjukkan bahwa kinerja keuangan yang meliputi kinerja likuiditas, leverage, aktivitas dan profitabilitas mampu memprediksi kondisi financial distress, sementara sensitivitas perusahaan terhadap inflasi dan nilai tukar tidak mampu memprediksi kondisi financial distress perusahaan.
\end{abstract}

Kata Kunci: Financial distress, kinerja keuangan, ekonomi makro.

\begin{abstract}
Identifying a financial distress condition is important because it can become an early warning system before the bankruptcy. The purpose of this research is to examine and analyze the liquidity, leverage, activity, profitability, inflation sensitivity, and exchange rate sensitivity as predictor financial distress condition in manufacturing company listed in Indonesian Stock Exchange (ISE) in the year 2015 until 2019. Sampling technique used in the research is purposive sampling. The sample consist of 53 companies experiencing financial distress and a company not experiencing financial distress The data analysis technique is logistic regression The results of this research indicate that liquidity, leverage, profitability and activity can predict financial distress in a negative direction. Inflation sensitivity and IDR USD exchange rate sensitivity cannot predict the occurrence of financial distress in a company.
\end{abstract}

Keywords: Financial distress, financial performance, macro economic.

\section{Pendahuluan}

Financial distress merupakan kondisi keuangan perusahaan dalam keadaan tidak sehat atau krisis. Financial distress terjadi sebelum kebangkrutan dan saat perusahaan mengalami kerugian selama beberapa tahun. Model prediksi financial distress merupakan model yang dapat digunakan untuk memprediksi kondisi keuangan perusahaan di masa mendatang. Model ini dapat digunakan sebagai sistem peringatan dini (early warning system) bagi perusahaan agar tidak terjadi kebangkrutan. Kinerja keuangan dapat dijadikan dasar untuk memprediksi kondisi financial distress suatu perusahaan, yakni dengan menggunakan rasio-rasio keuangan yang ada. Kinerja keuangan tersebut meliputi kinerja likuiditas, leverage, aktivitas, dan profitabilitas.

Likuiditas menunjukkan kemampuan perusahaan dalam memenuhi kewajiban jangka pendeknya. Semakin tinggi likuiditas mengindikasikan perusahaan semakin likuid, sehingga probabilitas perusahaan untuk mengalami financial distress semakin kecil. Hasil penelitian Hidayat dan Meiranto (2014) dan Wulandari dan Musdholifah (2019), membuktikan bahwa tingginya likuiditas akan menurunkan kemungkinan perusahaan untuk mengalami financial distress. Leverage menunjukkan seberapa besar utang yang digunakan untuk mendanai perusahaan. Semakin tinggi leverage, semakin tinggi risiko yang dihadapi peusahaan, sehingga akan meningkatkan 
probabilitas financial distress. Riset Hidayat dan Meiranto (2014), memberikan hasil bahwa tingginya leverage akan meningkatkan probablitas perusahaan mengalami financial distress. Kinerja aktivitas mengukur kemampuan perusahaan dalam mengelola asset yang dimiliki untuk menghasilkan penjualan. Semakin tinggi aktivitas perusahaan mengindikasikan perusahaan semakin optimal dalam mengelola asetnya, sehingga perusahaan akan memperoleh laba dan akhirnya probabilitas kondisi financial distress akan turun. Studi yang dilakukan Hidayat dan Meiranto (2014) dan Oktarina (2018) membuktikan bahwa kinerja aktivitas berpengaruh negatif terhadap kemungkinan terjadinya financial distress perusahaan. Hasil berbeda diperoleh Sucipto dan Muazaroh (2016) dalam penelitiannya yang menunjukkan bahwa kinerja aktivitas tidak dapat memprediksi kondisi financial distress. Kinerja profitabiitas menunjukkan kemampuan perusahaan dalam memperoleh keuntungan. Semakin tinggi profitabilitas perusahaan akan menurunkan probabilitas financial distress. Hal ini disebabkan karena dengan laba yang dihasilkan perusahaan, dapat memenuhi kewajibannya untuk membayar dividen serta kewajiban keuangan lainnya, sehingga perusahaan akan terhindar dari financial distress. Hasil penelitian Sucipto dan Muazaroh (2016), Fahlevi dan Marlinah (2018), dan Wulandari dan Musdholifah (2019) membuktikan bahwa profitabilitas mampu menurunkan kemungkinan perusahaan mengalami financial distress

Selain kinerja keuangan, sensitivitas inflasi dan sensitivitas nilai tukar ditenggarai dapat digunakan sebagai prediktor kondisi financial. Hasil penelitian Oktarina (2018) menunjukkan bahwa sensitivitas kurs dapat memprediksi kondisi financial distress dengan arah negatif, sedangkan hasil penelitian Tsai et al. (2013) menunjukkan bahwa sensitivitas kurs tidak dapat memprediksi kondisi financial distress. Adanya research gap dari penelitian sebelumnya yang dilakukan, memotivasi peneliti untuk menguji kembali kinerja keuangan dan indikator makro ekonomi dalam memprediksi financial distress pada perusahaan manufaktur yang ada di Bursa Efek Indonesia. Indikator makro ekonomi yang digunakan pada penelitian sebelumnya hanya nilai tukar/kurs. Pengukuran indikator makro dengan menggunakan sensitivitas perusahaan terhadap inflasi dan nilai tukar merupakan novelty dari penelitian ini yang belum diuji pada penelitian sebelumnya. Berdasarkan uraian tersebut, maka tujuan dari penelitian ini adalah untuk menganalisis kinerja keuangan yang meliputi kinerja likuiditas, leverage, aktivitas dan profitabilitas serta sensitivitas perusahaan terhadap inflasi dan nilai tukar sebagai prediktor financial distress perusahaan manufaktur pada Bursa Efek Indonesia. Hasil penelitian ini memberikan kontribusi dalam pengembangan pengetahuan manajemen keuangan khususnya dalam bidang corporate finance. Kontribusi praktis dari penelitian ini adalah model financial distress untuk perusahaan manufaktur yang dapat digunakan sebagai early warning system bagi perusahaan agar tidak mengalami financial distress.

\section{Kajian Teoritis dan Hipotesis Financial Distress}

Financial distress merupakan kondisi dimana perusahaan sedang menghadapi masalah kesulitan keuangan. Berdasarkan pernyataan Platt dan Platt (2002) financial distress diartikan sebagai tahap penurunan kondisi keuangan yang terjadi sebelum terjadinya kebangkrutan ataupun likuidasi. Kondisi financial distress tercermin dari tidak tersedianya suatu dana atau ketidakmampuan perusahaan dalam membayar semua kewajiban yang telah jatuh tempo. Platt dan Platt (2002) menyatakan bahwa terdapat tujuh indikator perusahaan dapat dikatakan mengalami kondisi financial distress, yaitu: (1) Perusahaan mengalami laba bersih negatif selama beberapa tahun, (2) Pemenuhan arus kas hasil operasi terhadap kewajiban perusahaan yang tidak cukup, (3) Perusahaan yang mengalami Earning Before Interest and Tax (EBIT) negatif, (4) Kekayaan bersih negatif dan nilai hutang yang lebih tinggi dibandingkan nilai asset, (5) Rendahnya arus kas dibandingkan dengan hutang jangka panjang saat ini, (6) Laba bersih operasi mengalami penurunan di beberapa tahun, dan (7) pembayaran dividen yang tidak dilakukan selama lebih dari satu tahun, (8) Memiliki Earning Per Share (EPS) bertanda negatif.

\section{Kinerja Likuiditas Sebagai Prediktor Kondisi Financial Distress}

Likuiditas menunjukkan kemampuan perusahaan untuk membayar kewajiban jangka pendek pada saat jatuh tempo dengan menggunakan aset lancar yang tersedia (Sucipto \& Muazaroh, 2016). Dalam penelitian ini rasio likuiditas yang digunakan ialah rasio lancar (current ratio), yang mengukur kemampuan perusahaan dalam membayar kewajiban jangka pendeknya yang telah jatuh tempo dengan menggunakan seluruh asset lancar yang dimiliki yang meliputi kas, piutang dan persediaan. Semakin tinggi likuiditas menunjukkan bahwa perusahaan semakin Jika perusahaan tersebut mampu mendanai serta memenuhi kewajiban jangka pendeknya dengan baik, maka kemungkinan perusahaan tersebut untuk mengalami kondisi financial distress juga akan semakin kecil. Jika perusahaan likuid, maka akan meningkatkan kredibilitas perusahaan. Hal ini sangat penting, sehingga akan memudahkan perusahaan untuk memperoleh sumber dana jangka pendek, misalnya utang usaha, yakni utang 
yang diperoleh dari supplier bahan baku. Adanya kemudahan mendapatkan bahan baku akan memperlancar proses produksi, sehingga akan meningkatkan omset penjualan dan pada akhirnya perusahaan akan memperoleh laba operasi, Adanya laba operasi yang tinggi mengakibatkan perusahaan terhindar dari financial distress. Hasil studi Hidayat dan Meiranto (2014) dan Wulandari dan Musdholifah (2019) memberikan bukti bahwa tingginya likuiditas akan menurunkan kemungkinan perusahaan untuk mengalami financial distress.

$\boldsymbol{H}_{\boldsymbol{I}}$ : Likuiditas mampu memprediksi kondisi financial distress.

\section{Kinerja Leverage Sebagai Prediktor Kondisi Financial Distress}

Leverage merupakan rasio solvabilitas yang mengukur kemampuan perusahaan dalam memenuhi kewajiban-kewajibannya, baik itu jangka pendek maupun jangka panjang jika pada suatu saat perusahaan tersebut dilikuidasi. Rasio ini menunjukkan seberapa banyak aset perusahaan yang didanai dari hutang. Pengukuran leverage yang digunakan yaitu Debt to Equity Ratio (DER). Semakin tinggi DER menunjukkan komposisi total hutang (jangka pendek dan jangka panjang) semakin besar dibanding dengan total modal sendiri, sehingga berdampak semakin besar beban perusahaan terhadap pihak luar (kreditur). Jika rasio DER ini menunjukkan hasil yang besar atau tinggi, maka dapat disimpulkan semakin besar juga porsi penggunaan hutang, sehingga akan mengakibatkan risiko keuangan perusahaan yang juga akan meningkat. Jika semakin besar proporsi hutang yang dimiliki oleh perusahaan, maka akan semakin besar juga risiko gagal bayar dan akan mengakibatkan kondisi financial distress atau bahkan mengarah kepada kebangkrutan perusahaan. Hal ini didukung oleh penelitian Hidayat dan Meiranto (2014) yang menunjukkan bahwa tingginya leverage akan meningkatkan probablitas perusahaan mengalami financial distress.

$\boldsymbol{H}_{2}$ : Kinerja leverage mampu memprediksi kondisi financial distress.

\section{Kinerja Aktivitas Sebagai Prediktor Kondisi Financial Distress}

Aktivitas menunjukkan efektivitas perusahaan dalam mengelola asetnya. Dalam penelitian ini rasio aktivitas diukur dengan menggunakan Total Asset Turnover Ratio (TATO), yaitu dengan membagi total penjualan dengan total aset yang dimiliki oleh perusahaan. Rasio tersebut digunakan untuk mengukur kemampuan perusahaan dalam menggunakan seluruh asetnya secara efektif untuk menghasilkan penjualan. Penelitian Hidayat dan Meiranto (2014) dan Oktarina (2018) membuktikan bahwa kinerja aktivitas yang diukur dengan menggunakan Total Aset Turnover Ratio (TATO) berpengaruh negatif terhadap kemungkinan terjadinya financial distress perusahaan.

$\boldsymbol{H}_{3}$ : Kinerja aktivitas mampu memprediksi terjadinya kondisi financial distress.

\section{Kinerja Profitabilitas Sebagai Prediktor Kondisi Financial Distress}

Profitabilitas menunjukkan kemampuan perusahaan dalam memperoleh keuntungan atau laba dalam suatu periode tertentu. Semakin tinggi profitabilitas semakin efisiensi perusahaan tersebut dalam mengelola seluruh aktiva dan investasi yang dimiliki untuk menghasilkan laba. Dengan demikian kemungkinan perusahaan mengalami financial distress akan semakin kecil pula. Jika perusahaan memperoleh laba, maka sebagian laba dibagikan kepada pemegang sahan dan sebagian yang lain merupakan saldo laba. Saldo laba ini merupakan sumber dana internal yang dapat dimanfaatkan perusahaan untuk meningkatkan produksinya yang pada akhirnya dapat meningkatkan omset penjualan, sehingga laba operasi juga meningkat. Dengan demikian perusahaan terhindar dari financial distress. Dalam penelitian ini profitabilitas diukur dengan menggunakan rasio return on equity (ROE) yang menunjukkan kemampuan perusahaan salam mengelola seluruh ekuitas yang dimiliki untuk dapat menghasilkan laba. Studi yang dilakukan Sucipto dan Muazaroh (2016), Fahlevi dan Marlinah (2018), dan Wulandari dan Musdholifah (2019) membuktikan bahwa profitabilitas mampu menurunkan kemungkinan perusahaan mengalami financial distress. Hal ini berarti kinerja profitabilitas merupakan prediktor financial distress.

$\boldsymbol{H}_{4}$ : Kinerja profitabilitas mampu memprediksi terjadinya kondisi financial distress.

\section{Sensitivitas Inflasi Sebagai Prediktor Kondisi Financial Distress}

Inflasi adalah kecenderungan terjadinya kenaikan tingkat harga barang secara umum, yang dapat diukur dengan suatu ukuran tingkat harga rata-rata atau disebut dengan istilah indeks harga. Ketika tingkat inflasi tinggi harga barang mangalami kenaikan, hal tersebut mengakibatkan permintaan masyarakat akan cenderung turun. Kondisi tersebut dapat menghambat kegiatan produksi perusahaan karena penjualan menurun seiring dengan rendahnya permintaan (Prasetyo \& Darmawan, 2017). Inflasi yang dimaksud dalam penelitian ini adalah 
kepekaan perusahaan akibat terjadinya peningkatan harga-harga produk secara keseluruhan atau yang disebut dengan sensitivitas inflasi. Semakin tinggi nilai sensitivitas inflasi, maka semakin tinggi juga risiko perusahaan dalam menghadapi kenaikan harga barang yang mengakibatkan turunnya permintaan terhadap produk perusahaan. Penurunan permintaan tersebut selanjutkan akan mengakibatkan turunnya omset penjualan yang pada akhirnya laba operasi perusahaan juga akan menurun. Hal inilah yang menyebabkan peruhaan mengalami financial distress. Jadi semakin sensitif perusahaan terhadap inflasi, semakin besar kemungkinan perusahaan mengalami financial distress, yang artinya sensitivitas terhadap inflasi merupakan prediktor financial distress.

$\boldsymbol{H}_{5}$ : Sensitivitas inflasi mampu memprediksi terjadinya kondisi financial distress.

\section{Sensitivitas Kurs Sebagai Prediktor Kondisi Financial Distress}

Kurs merupakan sebagai harga mata uang luar negeri dalam satuan mata uang dalam negeri. Kurs mata uang asing mengalami perubahan nilai yang terus menerus dan relatif tidak stabil. Perubahan nilai ini dapat terjadi karena adanya perubahan permintaan dan penawaran atas suatu nilai mata uang asing pada masingmasing pasar pertukaran valuta dari waktu ke waktu. Kurs yang dimaksud dalam penelitian ini adalah kepekaan perusahaan terhadap perubahan nilai tukar. Nilai tukar rupiah memiliki pengaruh utama terhadap perusahaan yang mengandalkan bahan baku impor. Untuk perusahaan yang mengandalkan bahan baku impor seperti Indonesia, maka pelemahan nilai tukar akan menurunkan daya beli masyarakat karena harus membayar dengan jumlah yang lebih banyak, sehingga akan menurunkan pendapatan perusahaan dan probabilitas terjadinya kondisi financial distress akan meningkat.

$\boldsymbol{H}_{6}$ : Sensitivitas Kurs mampu memprediksi terjadinya kondisi financial distress.

Berdasarkan kajian teori dan empiris serta hipotesis yang telah dirumuskan, berikut disajikan kerangka konseptual dari penelitian ini dalam Gambar 1.

\section{METODE PENELITIAN}

\section{Klasifikasi Sampel}

Dalam penelitian ini populasi yang digunakan adalah seluruh perusahaan manufaktur yang terdaftar di dalam Bursa Efek Indonesia (BEI) periode penelitian selama 2015-2019. Pengambilan sampel dilakukan secara purposive. Sampel yang digunakan dalam penelitian ini terdiri dari dua kelompok, yakni perusahaan manufaktur yang mengalami kondisi financial distress yang diindikasikan dengan laba operasi negatif dan perusahaan mnufaktur yang tidak mengalami kondisi financial distress yang diindikasikan dengan laba operasi positif dimana total asset setara dengan perusahaan yang mengalami financial distress. Terdapat 265 observasi yang terdiri dari 69 observasi perusahaan financial distress sisanya non financial distress.

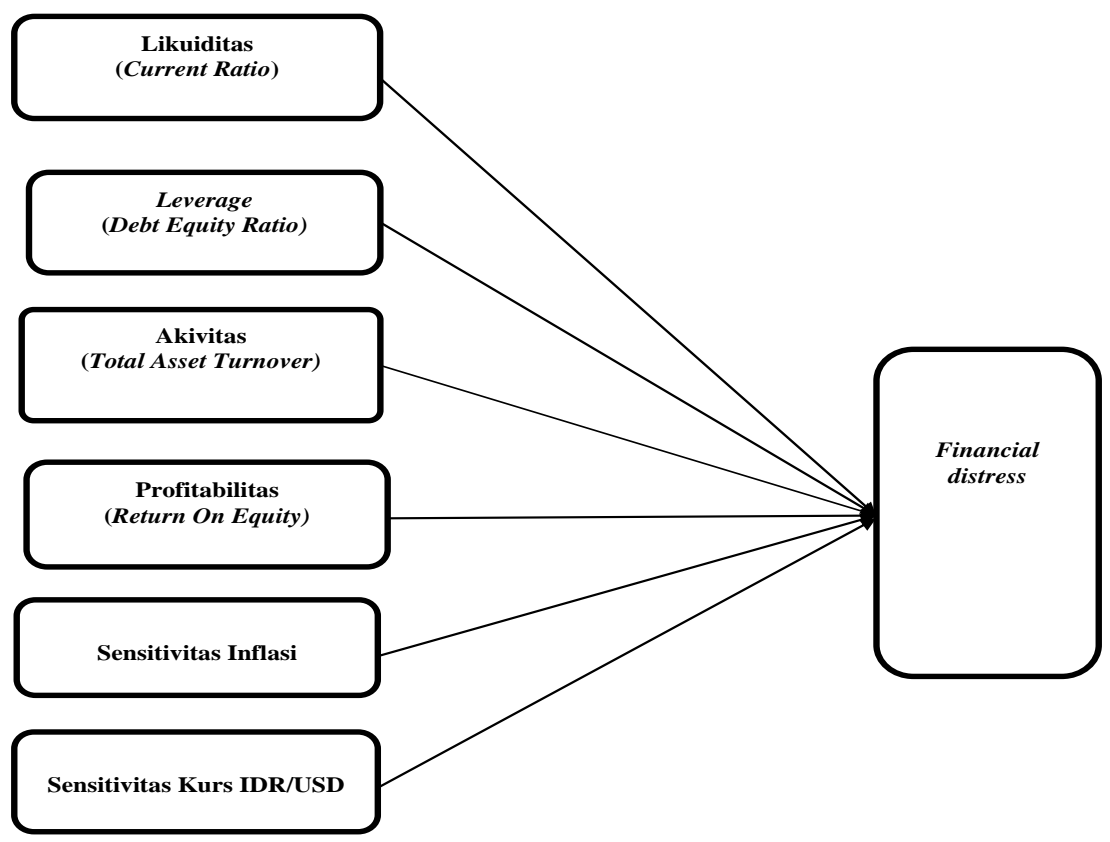

Gambar 1. Kerangka Penelitian 


\section{Data Penelitian}

Dalam penelitian ini data yang digunakan adalah data kuantitif dengan sumber data nya adalah data sekunder yang berupa data tentang laporan keuangan perusahaan manufaktur selama periode 2015-2019 yang terdapat di www.idx.-co.id (IDX), Indonesia Capital Market Directory (ICMD), dan situs resmi Badan Pusat Statistik.

\section{Variabel Penelitian}

Penelitian ini menggunakan variabel yang meliputi variabel dependen yaitu financial distress (Y) dan variabel independen $(X)$ terdiri dari kinerja likuiditas, leverage, aktivitas, profitabilitas, sensitivitas inflasi, dan sensitivitas kurs. Pengukuran variabel disajikan pada Tabel 1.

\section{Teknik Pengumpulan dan Analisis Data}

Data dalam penelitian dalam penelitian ini adalah data kuantitatif dengan skala pengukuran rasio untuk variabel kinerja keuangan dan sensitivitas perusahaan terhadap inflasi dan nilai tukar serta nominal untuk pengukuran financial distress. Data penelitian bersumber dari dat sekunder berupa laporan keuangan perusahaan sampel tahun 2015-2019 yang dirujuk dari www.idx.co.id (IDX), Indonesia Capital Market Directory (ICMD), dan situs resmi Badan Pusat Statistik.

Tabel 1

Pengukuran Variabel

\begin{tabular}{|c|c|c|}
\hline Variabel & Indikator & Pengukuran \\
\hline Financial Distress & Laba Operasi negatif & $\begin{array}{l}1=\text { Financial Distress } \\
0=\text { Non Financial Distress }\end{array}$ \\
\hline Likuiditas & Current Ratio (CR) & $\frac{\text { Aktiva Lancar }}{\text { Hutang Lancar }} \times 100 \%$ \\
\hline Leverage & Debt Equity Ratio (DER) & $\frac{\text { Total Kewajiban }}{\text { Total Ekuitas }}$ \\
\hline Aktivitas & Total Asset Turnover (TATO) & $\frac{\text { Penjualan }}{\text { Total Aktiva }} \times 1$ kali \\
\hline Profitabilitas & Return on Equity (ROE) & $\frac{\text { Laba Bersih }}{\text { Total Ekuitas }} \times 100 \%$ \\
\hline Inflasi & Sensitivitas Inflasi & CRi $=\beta 0+\beta$ inflasi + ei \\
\hline Kurs & Sensitivitas Kurs Tengah & CRi $=\beta 0+\beta$ kurs + ei \\
\hline
\end{tabular}

Teknik analisis data yang digunakan terdiri dari dua, yakni analisis deskriptif yang digunakan untuk memberikan gambaran tentang variabel yang diteliti secara univariate, dan analisis inferensial untuk menguji hipotesis. Adapun alat analisis yang digunakan adalah binomial logistic regression. Untuk menguji model fit atau tidak, digunakan Hosmer and Lemeshow Test dan -2log likelihood . Jika signifikansi uji ini lebih dari 0,05 atau terjadi penurunan nilai $2 \log$ likelihood mengindikasikan bahwa model fit untuk digunakan memprediksi financial distress. Selanjutnya untuk menguji hipotesis yang telah dirumuskan, digunakan nilai signifikansi dari Wald Statistic. Jika nilai signifikansi < 0,05, maka hipotesis penelitian dapat diterima dan sebaliknya.

\section{Analisis Data dan Pembahasan}

Tujuan dari penelitian adalah untuk memprediksi kondisi financial distress perusahaan manufaktur berdasarkan kinerja keuangan dan sensitivitas perusahaan terhadap inflasi dan nilai tukar. Hasil analisis deskriptif dan pengujian hipotesis disajikan pada sesi berikut ini

\section{Hasil Deskripsi Variabel Penelitian}

Variabel penelitian dalam penelitian ini meliputi kinerja keuangan dan sensitivitas perusahaan terhadap inflasi dan nilai tukar yang ditenggarai mampu memprediksi kondisi financial distress. Tabel 2 menunjukkan nilai statistik variabel penelitian. 
Dari Tabel 2 dapat diketahui bahwa rata-rata kinerja keuangan kelompok perusahaan financial distress lebih rendah dibanding kelompok non financial distress. Hal ini dapat dapat dijelaskan bahwa perusahaan financial distress tidak dapat mengoptimalkan asetnya dalam perolehan laba. Kinerja likuiditas perusahaan pada kelompok financial distress lebih rendah dibanding non financial distress. Hal ini dapat dijelaskan bahwa kemampuan perusahaan dalam kelompok financial distress dalam memenuhi kewajiban jangka pendek tidak sebaik perusahaan non financial distress. Rata-rata kinerja likuiditas perusahaan financial distress 162,22 persen sementara rata-rata likuiditas perusahaan non financial distress sebesar 211,79 persen. Kinerja yang lain, misalnya profitabilitas juga dapat diketahui bahwa rata-rata profitabilitas perusahaan non financial distress juga lebih rendah dibanding perusahaan non financial distress bahkan bernilai negatif yakni $-5,58$ persen.

Tabel 2

Deskripsi Variabel Penelitian

\begin{tabular}{llrr}
\hline \multicolumn{1}{c}{ Variabel } & & NFD & FD \\
\hline \multirow{2}{*}{ Likuiditas } & Mean & 211,79 & 162,22 \\
& Std. Deviasi & 154,85 & 105,18 \\
Leverage & Mean & 1,44 & 1,37 \\
& Std. Deviasi & 1,56 & 1,17 \\
Aktivitas & Mean & 1,09 & 0,73 \\
& Std. Deviasi & 0,92 & 0,49 \\
Profitabilitas & Mean & 6,07 & $-5,58$ \\
& Std. Deviasi & 23,75 & 15,78 \\
\multirow{2}{*}{ Sens.Inflasi } & Mean & 11,46 & 26,29 \\
\multirow{2}{*}{ Sens.Kurs } & Std. Deviasi & 279,83 & 206,39 \\
& Mean & $-0,162$ & $-0,036$ \\
& Std. Deviasi & 1,26 & 0,58 \\
\hline
\end{tabular}

Sumber: www.idx.co.id, periode 2015-2019, data diolah

Hal ini dapat dijelaskan bahwa sebagian besar perusahaan dalam kelompok non financial distress mengalami kerugian. Kerugian ini disebabkan karena beban operasional yang terlalu tinggi, sehingga laba operasional menjadi negatif. Kinerja aktivitas perusahaan kelompok financial distress sebesar 0,73 juga lebih kecil dibanding peruhaan non financial distress. Hal ini mengindikasikan bahwa perusahaan financial distress tidak mampu mengoptimal pemanfaat asetnya untuk menghasilkan penjualan Berdasarkan sensitivitas perusahaan terhadap inflasi dan nilai tukar, dapat diketahui bahwa perusahaan financial distress lebih sensitif terhadap perubahan inflasi dibanding kelompok non financial distress. Hal ini dapat dilihat dari nilai rata-rata sensitivitas inflasi kelompok financial distress 26,29, sementara non financial distress yang hanya 11,46.

\section{Hasil Regresi Logistik}

Analisis regresi logistik dalam penelitian ini digunakan untuk menguji kekuatan prediksi likuiditas, leverage, aktivitas, profitabilitas, sensitivitas inflasi dan sensitivitas kurs terhadap kondisi financial distress. Hasil Tabel 3 memperlihatkan bahwa koefesien regresi logistik untuk kinerja keuangan yang meliputi kinerja likuiditas, leverage, aktivitas dan profitabilitas bernilai negatif, sementara sensitivitas perusahaan terhadap inflasi bernilai nol dan sensitivitas terhadap nilai tukar bernilai positif. Hal ini dapat dijelaskan bahwa semakin tinggi kinerja keuangan yang dicapai perusahaan akan menurunkan probabilitas perusahaan mengalami financial distress. Sementara semakin sensitif perusahaan terhadap nilai tukar semakin besar probabilitas perusahaan mengalami financial distress.

Model prediksi yang dihasilkan dalam penelitian ini terbukti fit. Hal ini dapat dilihat dari nilai signifikan Hosmer 0,307 > 0,05 serta adanya penurunan nilai Initial -2 Log Likehood Block 0 sebesar 292,414 menjadi 256,213 Initial -2 Log Likehood Block 1Likehood Block 0 -2 Log Likehood Block 1 Selanjutnya dapat dilihat nilai Nagelkerke R2 sebesar 0,192 yang menunjukkan bahwa hanya sebesar 19,2persen kondisi financial distress perusahaan manufaktur dapat diprediksi oleh kinerja keuangan dan sensitivitas perusahaan terhadap inflasi dan nilai tukar, sisanya sebesar 80,8 persen ditentukan oleh faktor lain yang belum dimasukkan dalam model penelitian.

Total daya prediksi model sebesar 0.785 yang menunjukkan akurasi model yang ditemukan dalam penelitian ini sebesar 78.5 persen. Kinerja keuangan yang meliputi likuiditas, leverage, aktivitas dan profitabilitas serta sensitivitas perusahaan terhadap inflasi dan nilai tukar secara simultan mampu memprediksi kondisi 
financial distress. Nilai p-value masing-masing kinerja keuangan yang terdiri dari kinerja likuiditas, leverage, aktivitas dan profitabilitas lebih kecil dari 0,05 artinya bahwa $H_{o}$ ditolak atau $H_{l}, H_{2}, H_{3}$, dan $H_{4}$ dapat diterima. Hal ini dapat dijelaskan bahwa kinerja likuiditas, leverage, aktivitas dan profitabilitas secara parsial mampu memprediksi financial distress atau dengan kata lain kinerja keuangan merupkan prediktor financial distress. Sementara sensitivitas perusahaan terhadap inflasi dan nilai tukar tidak terbukti mampu memprediksi kondisi financial distress, yang berarti $H_{5}$ dan $H_{6}$ ditolak.Hal ini didasarkan pada nilai $p$-value yang lebih besar dari 0,05 .

Tabel 3

Ringkasan Analisis Regresi Logistik

\begin{tabular}{|c|c|c|c|}
\hline Keterangan & Variabel & $B$ & Sig. \\
\hline \multirow{7}{*}{ Variables in the Equation } & Likuiditas & $-0,004$ & 0,013 \\
\hline & Leverage & $-0,578$ & 0,002 \\
\hline & Aktivitas & $-0,874$ & 0,014 \\
\hline & Profitabilitas & $-0,033$ & 0,000 \\
\hline & Sens. Inflasi & 0,000 & 0,860 \\
\hline & Sens,Kurs & 0,088 & 0,522 \\
\hline & Constant & 1,233 & 0,019 \\
\hline Hosmer and Lemeshow Test & Sig. & & 0,307 \\
\hline \multirow{2}{*}{ Iteration History } & Initial -2 Log Likehood Block O & & 292,414 \\
\hline & Initial-2 Log Likehood Block 1 & & 256,213 \\
\hline Classification Table & Overall Percentage & & 0,785 \\
\hline Model Summary & $R^{2}$ & & 0,192 \\
\hline
\end{tabular}

Sumber: www.idx.co.id, periode 2015-2019, data diolah

\section{Pembahasan}

\section{Likuiditas Sebagai Prediktor Kondisi Financial Distress}

Hasil pengujian membuktikan bahwa likuiditas mampu memprediksi kondisi financial distress dengan arah negatif. Hal ini dapat dijelaskan bahwa semakin tinggi likuiditas yang dihasilkan perusahaan, maka semakin likuid perusahaan tersebut dan semakin banyak asset yang bisa dikonversikan menjadi uang tunai dan digunakan untuk melunasi kewajiban jangka pendeknya. Perusahaan yang likuid akan meningkatkan kredibilitas perusahaan, sehingga memudahkan perusahaan mendapatkan sumber pendanaan yang berasal dari utang usaha. Adanya kemudahan mendapatkan bahan baku akan memperlancar proses produksi, sehingga akan meningkatkan omset penjualan dan pada akhirnya perusahaan akan memperoleh laba operasi, Adanya laba operasi yang tinggi mengakibatkan perusahaan terhindar dari financial distress. Hal ini menunjukkan bahwa risiko gagal bayar dan probabilitas terjadinya kondisi financial distress akan semakin kecil. Hasil ini selaras dengan studi Hidayat dan Meiranto (2014) dan Wulandari dan Musdholifah (2019) yang juga berhasil membuktikan bahwa likuiditas berpengaruh negatif terhadap financial distress, yang berarti tingginya likuiditas akan menurunkan kemungkinan perusahaan untuk mengalami financial distress. Hasil dari penelitian ini menemukan bukti bahwa likuiditas merupakan prediktor financial distress.

\section{Leverage Sebagai Prediktor Kondisi Financial Distress}

Berdasarkan hasil penelitian diperoleh bukti bahwa leverage mampu memprediksi kondisi financial distress dengan arah negatif, artinya semakin tingggi leverage, maka semakin kecil probabilitas terjadinya kondisi financial distress pada suatu perusahaan. Bukti pengujian ini tidak sejalan dengan penelitian Hidayat dan Meiranto (2014) yang memberikan hasil bahwa tinggi leverage akan meningkatkan probablitas perusahaan mengalami financial distress. Namun hasil ini penelitian ini mendukung teori Modigliani Miller dengan pajak, yang menyatakan bahwa penggunaan hutang dapat meningkatkan value of the firm karena biaya hutang adalah biaya yang akan mengurangi pembayaran pajak. Dengan meningkatnya nilai perusahaan ini, maka akan mengakibatkan laba yang dihasilkan perusahaan juga mengalami peningkatan, sehingga akan memperkecil probabilitas terjadinya kondisi financial distress. Hasil pengujian yang telah dilakukan berhasil menemukan bukti empiris bahwa leverage merupkan prediktor financial distress.

\section{Aktivitas Sebagai Prediktor Kondisi Financial Distress}

Berdasarkan hasil pengujian pada Tabel 3 dapat diketahui bahwa aktivitas mampu memprediksi kondisi financial distress pada suatu perusahaan dengan arah negatif. Hasil ini dapat dijelaskan bahwa jika suatu 
perusahaan memiliki tingkat penjualan tinggi, berarti perusahaan dapat mengelola asetnya dengan optimal. Jika perusahaan mampu memnafaatkan asetnya dengan optimal, maka perusahaan akan dapat meningkatkan penjualan. Peningkatan penjualan ini akan berdampak pada peningkatan laba operasional perusahaan pada tahun mendatang, sehingga probabilitas terjadinya kondisi financial distress akan semakin kecil. Bukti Empiris ini mendukung studi Hidayat dan Meiranto (2014) dan Oktarina (2018) yang menyatakan bahwa kinerja aktivitas yang diukur dengan menggunakan Total Aset Turnover Ratio (TATO) berpengaruh negatif terhadap kemungkinan terjadinya financial distress perusahaan. Hal ini dapat dijelaskan bahwa semakin tinggi aktivitas perusahaan dalam mengoptimalkan asetnya untuk menghasilkan penjualan, maka akan semakin turun probabilitas perusahaan untuk mengalami kondisi financial distress. Temuan dalam penelitian ini adalah kinerja aktivitas merupakan prediktor financial distress.

\section{Profitabilitas Sebagai Prediktor Kondisi Financial Distress}

Berdasarkan hasil pengujian pada Tabel 3 dapat diperoleh hasil bahwa profitabilitas mampu memprediksi kondisi financial distress dengan arah negatif, yang berarti semakin tinggi kemampuan perusahaan dalam menghasilkan laba dengan ekuitas yang dimiliki, akan meningkatkan laba operasi yang dihasilkan oleh perusahaan, sehingga kemungkinan perusahaan akan mengalami kondisi financial distress akan semakin kecil. Jika pada saat ini perusahaan berhasil membukukan profit yang tinggi, maka sebagian profit tersebut merupakan saldo laba yang dapat digunakan sebagai modal internal perusahaan untuk pemenuhan operasional periode mendatang. Semakin besar laba yang diperoleh semakin besar pula modal internal yang dapat digunakan untuk menunjang operasional peruhasaan pada periode mendatang, sehingga kan meningkatkan penjualan. Peningkatan penjualan tersebut akan meningkatkan laba operasional perusahaan yang pada akhirnya perusahaan terhindar dari financial distress. Temuan ini selaras dengan penelitian Sucipto dan Muazaroh (2016), Fahlevi dan Marlinah (2018), dan Wulandari dan Musdholifah (2019) yang berhasil membuktikan bahwa profitabilitas mampu menurunkan kemungkinan perusahaan mengalami financial distress. Pengujian yang dilakukan dalam penelitian ini berhasil membuktikan bahwa profitabilitas merupakan prediktor financial distress.

\section{Sensitivitas Inflasi Sebagai Prediktor Kondisi Financial Distress}

Berdasarkan hasil penelitian diperoleh hasil bahwa sensitivitas perusahaan terhadap inflasi tidak dapat digunakan untuk memprediksi kondisi financial distress pada suatu perusahaan. Sensitivitas inflasi dalam dalam penelitian ini tidak dapat memprediksi kondisi financial distress disebabkan karena mayoritas sampel dari perusahaan manufaktur dalam penelitian ini adalah perusahaan yang menyediakan kebutuhan primer dan sekunder, sehingga peningkatan inflasi tidak akan menurunkan minat masyarakat terhadap barang karena tetap membutuhkan barang tersebut, selain itu upah minimum regional (UMR) juga semakin naik yang artinya tingkat pendapatan masyarakat semakin naik sehingga meskipun harga barang naik tidak akan menurunkan daya beli masyarakat. Minat masyarakat yang tidak mengalami penurunan ini akan menyebabkan perusahaan masih dapat menjual barang produksinya, sehingga tidak mengurangi pendapatan perusahaan. Hasil ini tidak mampu mendukung teori Purchasing Power Parity yang menyatakan bahwa kenaikan inflasi akan menurunkan daya beli masyarakat.

\section{Sensitivitas Kurs Sebagai Prediktor Kondisi Financial Distress}

Berdasarkan penelitian dapat diperoleh bahwa sensitivitas perusahaan terhadap kurs IDR/USD tidak mampu memprediksi terjadinya kondisi financial distress dalam suatu perusahaan. Hal ini disebabkan karena mayoritas sampel dari perusahaan manufaktur pada penelitian ini adalah perusahaan yang menyediakan kebutuhan primer dan sekunder, sehingga peningkatan nilai tukar tidak akan menurunkan minat masyarakat terhadap barang karena tetap membutuhkan barang tersebut, selain itu upah minimum regional (UMR) juga semakin naik yang artinya tingkat pendapatan masyarakat semakin naik, sehingga meskipun nilai tukar rupiah melemah tidak akan menurunkan daya beli masyarakat. Perusahan tetap mampu menjual produknya dan menghasilkan pendapatan. Kurs erat kaitannya dengan kegiatan ekspor dan impor suatu perusahaan, ketika dilihat dari sisi impor melemahnya kurs akan menurunkan daya beli masyaraka karena harus membayar dalam jumlah yang besar. Namun berbeda jikalau dilihat dari sisi ekspor, ketika kurs melemah justru akan meningkatkan daya beli masyarakat. Meski mayoritas perusahaan di Indonesia masih mengandalkan bahan baku impor, namun Indonesia juga telah malakukan kegiatan ekspor yang cukup banyak. Hal ini menunjukkan bahwa pelemahan nilai kurs tidak selalu menurunkan daya beli masyarakat. 


\section{Simpulan, Keterbatasan, dan Saran}

Berdasarkan hasil analisis dan pembahasan yang telah dilakukan, dapat disimpulkan: pertama, bahwa kinerja keuangan yang meliputi kinerja likuiditas, leverage, aktivitas dan profitabilitas mampu memprediksi kondisi financial distress. Tingginya likuiditas yang dihasilkan perusahaan menunjukkan semakin banyak asset yang bisa dikonversikan menjadi uang tunai dan digunakan untuk melunasi kewajiban jangka pendeknya. Dengan demikian risiko gagal bayar dan probabilitas terjadinya kondisi financial distress akan semakin kecil. Kedua, leverage mampu memprediksi kondisi financial distress dengan arah negatif, artinya semakin tingggi leverage, maka semakin kecil probabilitas terjadinya kondisi financial distress. Penggunaan hutang dapat meningkatkan value of the firm karena biaya hutang adalah biaya yang akan mengurangi pembayaran pajak, sehingga laba meningkat. Meningkatnya laba akan menurunkan probabilitas financial distress. Ketiga, aktivitas mampu memprediksi kondisi financial distress dengan arah negatif, sehingga dapat disimpulkan peningkatan kinerja aktivitas akan menurunkan probabilitas financial distress. Keempat, profitabilitas mampu memprediksi kondisi financial distress dengan arah negatif, yang berarti semakin tinggi kemampuan perusahaan dalam menghasilkan laba dengan ekuitas yang dimiliki, akan meningkatkan laba operasi yang dihasilkan oleh perusahaan, sehingga kemungkinan perusahaan akan mengalami kondisi financial distress akan semakin kecil. Simpulan terakhir dalam penelitian ini adalah sensitivitas perusahaan terhadap inflasi dan nilai tukar tidak mampu memprediksi financial distress perusahaan manufaktur. Hal ini dapat disimpulkan bahwa pada perusahaan manufaktur, perubahan sensitivitas perusahaan terhadap inflasi dan nilai tukar tidak berdampak pada kondisi financial distress mengingat produk yang dihasilkan perusahaan manufaktur merupakan kebutuhan primer bagi perusahaan.

Keterbatasan dalam penelitian ini adalah kinerja keuangan dan sensitivitas perusahaan terhadap inflasi dan nikai tukar yang diuji dalam penelitian hanya mampu memprediksi financial distress sebesar 19,2 persen. Oleh karena itu, bagi peneliti selanjutnya disarankan untuk menambah variabel lain yang belum diuji dalam penelitian agar dapat diperoleh model penelitian yang lebih komprehensif, misalnya kepemilikan manajerial atau good corporate governance. Jumlah sampel perusahaan financial distress hanya sedikit yaitu 69 dari 265 observasi, hal ini dikarenakan pada penelitian ini hanya menggunakan laba operasi sebagai indikator financial distress. Disarankan bagi peneliti selanju-tnya untuk mengubah atau menambah indikator lain yang bisa digunakan untuk mengkategorikan perusahaan yang mengalami kondisi financial distress dan perusahaan yang tidak mengalami kondisi financial distress seperti menggunakan Earning Before interest and Tax (EBIT) atau Earning After Tax (EAT), sehingga observasi yang dihasilkan menjadi lebih banyak.

\section{Referensi}

Fahlevi, M. R., \& Marlinah, A. A. N. (2018). The influence of liquidity, capital structure, profitability and cash flows on the company's financial distress. Jurnal Bisnis dan Akuntansi, 20(1), 59-68. https://doi.org/ 10.34208/jba.v20i1.409

Hidayat, M. A., \& Meiranto, W. (2014). Prediksi financial distress perusahaan manufaktur di Indonesia (Studi empiris pada perusahaan manufaktur yang terdaftar di Bursa Efek Indonesia Periode 2008-2012). Skripsi, Fakultas Ekonomika dan Bisnis, Universitas Diponegoro.

Oktarina, D. (2018). Prediksi financial distress menggunakan rasio keuangan, sensitivitas makroekonomi dan intellectual capital. ULTIMA Accounting, 10(1), 16-33.

Platt, H. D., \& Platt, M. B. (2002). Predicting corporate financial distress: Reflections on choice-based sample bias. Journal of Economics and Finance, 26(2), 184-199. http://dx.doi.org/10.1007/ BF02755985

Prasetyo, D. A., \& Darmawan, A. (2017). Pengaruh risiko inflasi, risiko suku bunga, risiko nilai tukar dan leverage terhadap profitabilitas (Studi pada perusahaan sub sektor makanan dan minuman yang terdaftar di Bursa Efek Indonesia tahun 2012-2016). Jurnal Administrasi Bisnis (JAB), 50(3), 48-56.

Sucipto, A. W., \& Muazaroh, M. (2016). Kinerja rasio keuangan untuk memprediksi kondisi financial distress pada perusahaan jasa di Bursa Efek Indonesia periode 2009-2014. Journal of Business \& Banking, 6(1), 81-98. http://dx.doi.org/10.14414/jbb.v6i1.893

Wulandari, W., \& Musdholifah, M. (n.d.). Studi pengaruh corporate governance, likuiditas dan profitabilitas financial distress pada perusahaan sub sektor properti dan real estate di Indonesia. Jurnal Ilmu Manajemen, 7(4), 1104-1117. 